\title{
Influence of the state of meat market development on food self-sufficiency of the Russian Federation
}

\author{
Lyudmila Kopteva ${ }^{1, *}$ and Lyudmila Shabalina ${ }^{2}$ \\ ${ }^{1}$ Saint-Petrsburg State University of Aerospase Instrumentation, Bolshaya Morskaia str., 67, Saint- \\ Petersburg, 190000, Russia \\ ${ }^{2}$ Donetsk National Technical University, Artema str., 58, Donetsk, 83000, Ukraine
}

\begin{abstract}
The purpose of the study is to reveal the aspects of food selfsufficiency and the state of development of the meat products market of the Russian Federation. Objectives of the study. To analyze the current state of the development of the market for meat products and its influence on food self-sufficiency of the Russian Federation. Methods. In the course of the study, the following methods were used: methods of theoretical generalization and comparison, analysis and synthesis, methods of multivariate statistical analysis (for studying the state of the market of information and communication technologies in Russia).
\end{abstract}

\section{Introduction}

Beef cattle breeding is one of the areas of agriculture mainly used for raising cattle of beef breeds and for obtaining meat products.

Food security is an organized system that provides every segment of the population with food products according to generally recognized physiological norms.

In the economy of any country, food self-sufficiency is of particular importance. The country must have its own food production. Given the geographic location and differences in the provision of natural resources, the countries found themselves in unequal conditions in the production of certain food products. These circumstances force countries to resort to the import of materials, raw materials, as well as finished products of agricultural production.

However, in our opinion, the introduction of bans on the supply of imported products should be accompanied by an increase in domestic production, including an increase in financing of domestic agriculture. An important step for creating a favorable environment for an effective import substitution policy should be not only the production of a certain level of agricultural products to cover domestic demand, but also the increase in exports to other countries and the entry of Russian producers into global markets.

${ }^{*}$ Corresponding author: doptaganka@yandex.ru 
In order to implement the import substitution policy aimed at reducing the import of certain goods by stimulating and supporting domestic producers, a State program for the development of agriculture and regulation of agricultural products, raw materials and food markets for 2013-2020 was developed, and a "Road map" was approved to facilitate import substitution in agriculture, as well as amendments were made to the main document regulating the fundamentals of food security in Russia - the Food Security Doctrine of the Russian Federation. It is important to note that some legislative acts adopted earlier than 2014 and still in force today no longer reflect the real state of affairs. However, the legislative framework has expanded significantly in recent years, both in the federal and regional aspects, which is also a positive trend.

\section{Available information}

Ensuring food security of the country is considered a complex and multifaceted task. Due to the difficult geopolitical situation, our country was forced to face many problems in the field of food supplies.

L.E. Namyatova, M.G. Porvadov, T.A. Sharykina considered in their works aspects of food security of the Russian Federation. Issues of improving food security have been shown in the works of E.N. Polichkina and O.A. Medyanskaya. A deep analysis of the agricultural sector of the Russian Federation and its current state is studied in the orks of V.Ya. Uzun, N.I. Shagayda and D.A. Loginov. Innovative and investment development of agriculture is presented in the works of A.V. Kostikova and N.V. Klimova. Issues of agricultural regulation in the Russian Federation are considered in the works of S.Yu. Demin and O.I. Khamzina.

\section{Results of the study}

According to the authors of the paper, "The protracted global financial crisis that began in 2008 has a negative impact on global food production. So, for the period 2012-2016, the food security index of most developing countries fell by an average of 2 points. Food security is an integral part of the sustainable development of the world. Therefore, it is necessary to ensure the balance of food production and consumption, which depends on many different factors" [1].

The state of the meat industry in Russia.

The Russian meat industry is one of the largest and most important sectors of the agricultural industry and the food market of the Russian Federation (RF). "The importance of this market is determined not only by increasing volumes of production and consumption of meat products, but also by their importance as the main source of animal protein in the human diet." [2]

\section{Meat production in Russia}

In 2017 , the production of all types of meat increased by $15 \%$ compared to 2014 , while the highest growth was observed in pork and poultry production by $18 \%$, respectively (Table 1).

Table 1. Meat production of all economic categories in the Russian Federation [3].

\begin{tabular}{|l|l|l|l|l|l|l|l|l|l|l|}
\hline \multirow{3}{*}{ Indicators } & \multicolumn{10}{|c|}{ Years } \\
\cline { 2 - 9 } & 2008 & 2009 & 2010 & 2011 & 2012 & 2013 & 2014 & 2015 & 2016 & 2017 \\
\hline
\end{tabular}




\begin{tabular}{|l|c|c|c|c|c|c|c|c|c|c|}
\hline Pork, million tons & 2.84 & 2.17 & 2.33 & 2.43 & 2.57 & 2.82 & 2.97 & 3.10 & 3.6 & 3.51 \\
\hline Beef, million tons & 1.77 & 1.74 & 1.73 & 1.63 & 1.64 & 1.64 & 1.66 & 1.65 & 1.62 & 1.7 \\
\hline $\begin{array}{l}\text { Poultry meat, million } \\
\text { tons }\end{array}$ & 2.22 & 2.56 & 2.85 & 3.20 & 3.63 & 3.83 & 4.16 & 4.54 & 4.62 & 4.93 \\
\hline $\begin{array}{l}\text { Lamb and goat, } \\
\text { thousand tons }\end{array}$ & 0.15 & 0.17 & 0.17 & 0.17 & 0.17 & 0.19 & 0.20 & 0.20 & 0.22 & 0.22 \\
\hline $\begin{array}{l}\text { Other types of meat, } \\
\text { thousand tons }\end{array}$ & 0.04 & 0.04 & 0.05 & 0.06 & 0.07 & 0.09 & 0.09 & 0.09 & 0.09 & 0.11 \\
\hline Total, million tons & 7.02 & 6.67 & 7.12 & 7.49 & 8.08 & 8.56 & 9.09 & 9.58 & 10.19 & 10.46 \\
\hline
\end{tabular}

Self-sufficiency in certain types of meat have characteristic differences. For chicken meat, this indicator is $111.13 \%$, which means an excess of $11.13 \%$, for pork $-94.76 \%$, and is fully consistent with the norm, for beef $-57.33 \%$, which indicates a clear deficit and noncompliance with self-sufficiency standards - 85\%.

A steady increase in meat production in the Russian Federation is observed from 2001 to 2019 (Figure 1).

In the period over 5 years, production increased by $24.7 \%$, over 10 years - by $69.3 \%$, over 15 years - by $112.9 \%$. The total meat production in 2018 amounted to 10,629 thousand tons, which is 3,464 thousand tons more than in 2010 and 6,152 thousand tons more than in 2001 .

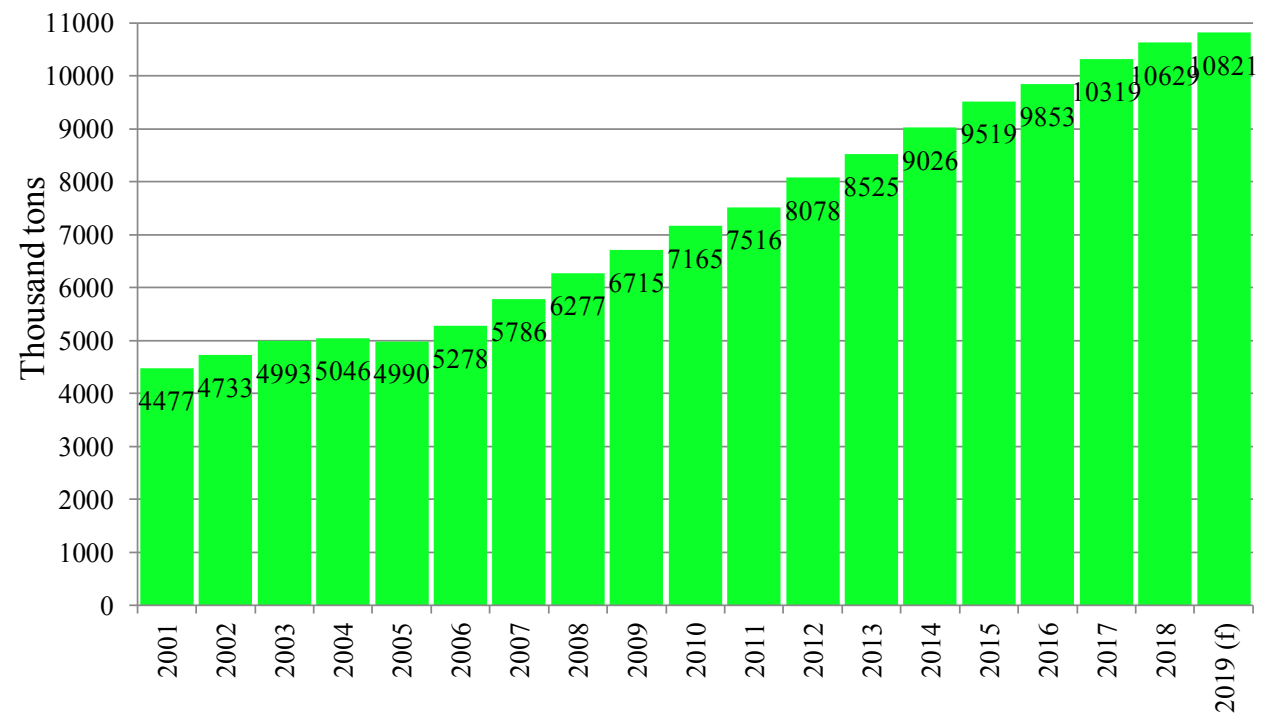

Fig. 1. Meat production in Russia in carcass weight in 2001-2018, forecast for 2019, thousand tons [4] (Source: The expert analytical center of agrobusiness "AB-Centre" [5]).

Analyzing the structure of meat production for 2001-2018, it can be seen that there is a tendency to increase the share of pork and poultry, while the proportion of beef gradually decreased. In 2018 , the share of pork amounted to $35.2 \%$, beef $-15.1 \%$, poultry meat $46.9 \%$, lamb $-1.9 \%$, goat meat $-0.2 \%$, other types of meat $-0.7 \%$. 
According to estimates of AB-Centre, the production of meat of all kinds in the Russian Federation in 2019 will amount to $10,820.9$ thousand tons, which is $1.8 \%$ more than in 2018 .

\section{Russian pork market}

A significant increase in production characterizes the Russian pork market. This was facilitated by the phased introduction of restrictions on the supply of imported products. For example, in August 2014, restrictions were introduced on the import of pork from the EU, the USA and Canada (which are still valid), from March to December 2018, there were practically no deliveries from Brazil. In addition, the devaluation of the ruble contributed to a reduction in the import of pork from abroad.

In 2018, meat production in carcass weight in farms of all categories reached 3,744.2 thousand tons. Over the year, production increased by $6.5 \%$, over 10 years - by $82.3 \%$ (Figure 2).

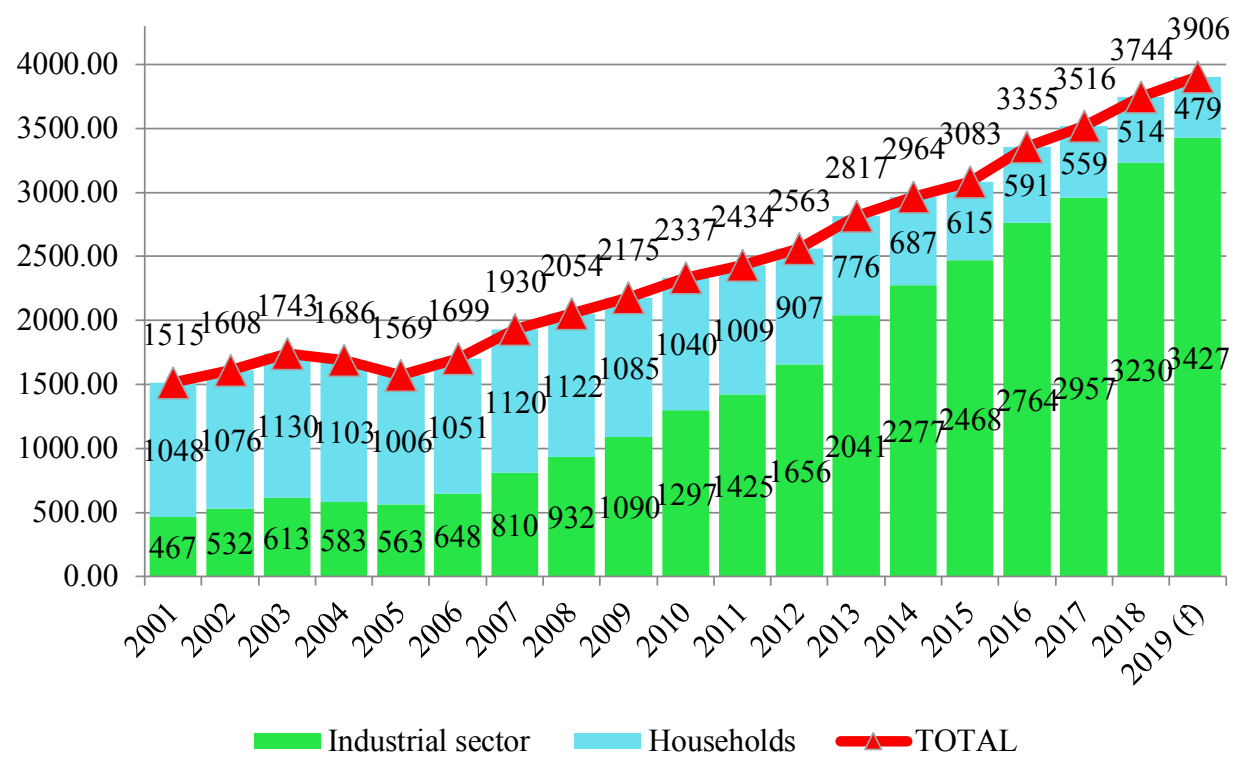

Fig. 2. Production of pork in carcass weight in farms of all categories in Russia in 2001-2018, forecast for 2019, thousand tons (Source: Rosstat (Russian Federal State Statistics Service), 2019 forecast by AB-Centre [4,5]).

At the same time, even more tangible growth is observed in the industrial sector of pig farming (by $9.2 \%$ per year, by $246.6 \%$ in 10 years) to 3,230.1 thousand tons. In households, on the contrary, production is reduced (by $8.0 \%$ per year, by $54.2 \%$ over 10 years) to 514.1 thousand tons.

In 2019, the increase in production will continue, although a slight slowdown in the growth rate is expected (it will increase by $4.7 \%$ to $3,919.1$ thousand tons) [6].

The leading position in the Russian market for the production of meat products is retained by poultry meat whose share is $47.2 \%$. It should be noted that it is produced by $17.7 \%$ more than in the world, which indicates its social significance due to the low price (Figure 3) [7]. 


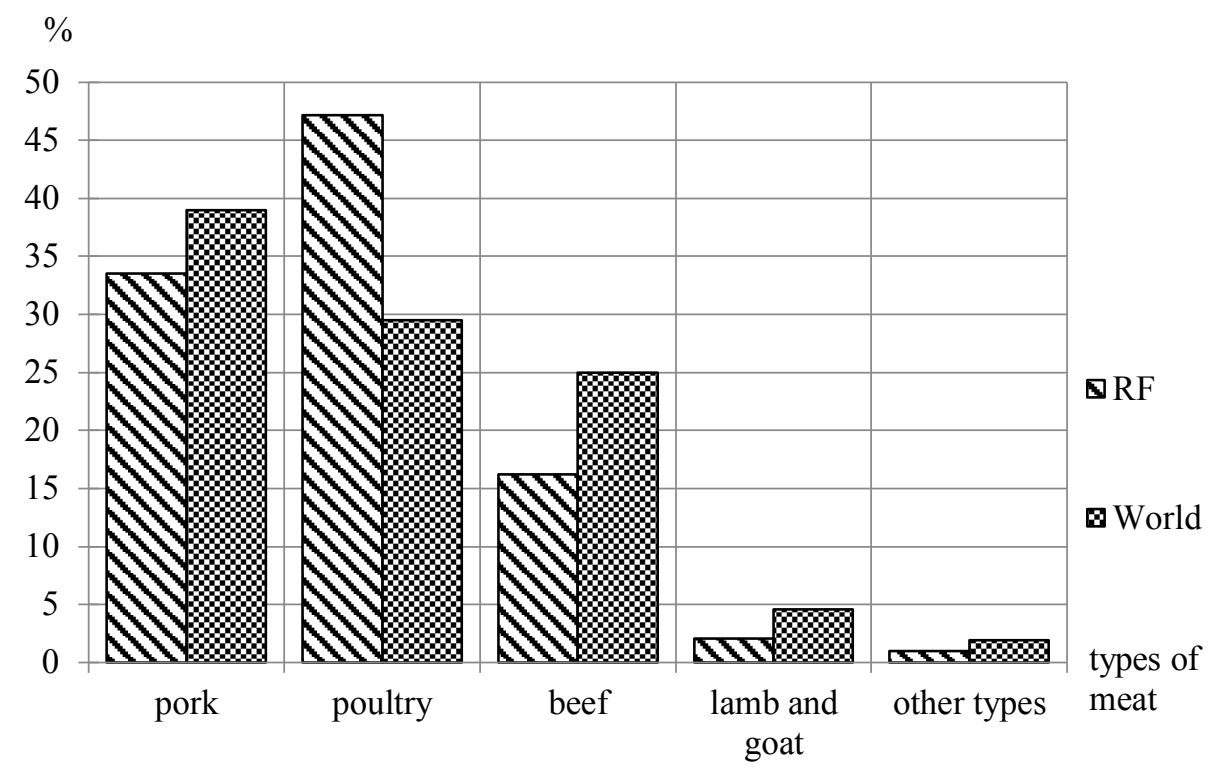

Fig. 3. Structure of meat production in the world and the Russian Federation, 2017.

For example, after the Russian Federation entered the WTO, the country's meat industry was significantly affected by increased competition due to a decrease in the duty rate on imports of livestock from $40 \%$ to $5 \%$, which led to lower prices and put the industry at risk. In these circumstances, the need for adaptation measures to support producers in the new realities arose. As a result, since 2014, the agricultural industry of the Russian Federation began to switch to a policy of accelerated import substitution of food products, which allowed Russian producers to expand the availability of goods in stores, as a result of which some foreign competitors left the market.

The situation on the Russian market of meat and meat products was influenced by a slight weakening in world prices, an increase in national production and the strengthening of the Russian ruble. These circumstances contributed to the saturation of the market with different types of meat and increased competition among Russian producers, which led to an increase in demand and lower prices. In 2014, compared to 2013, prices for pork meat increased by $14 \%$, which was due to an increase in the cost of feed, a shortage of meat in the market due to a drop in its imports and an increase in the livestock. In 2017, compared to 2008 , pork fell in price by $30.2 \%$, chicken meat - by $34.7 \%$. At the same time, a $5 \%$ decrease in the price of beef was observed (Figure 4). 


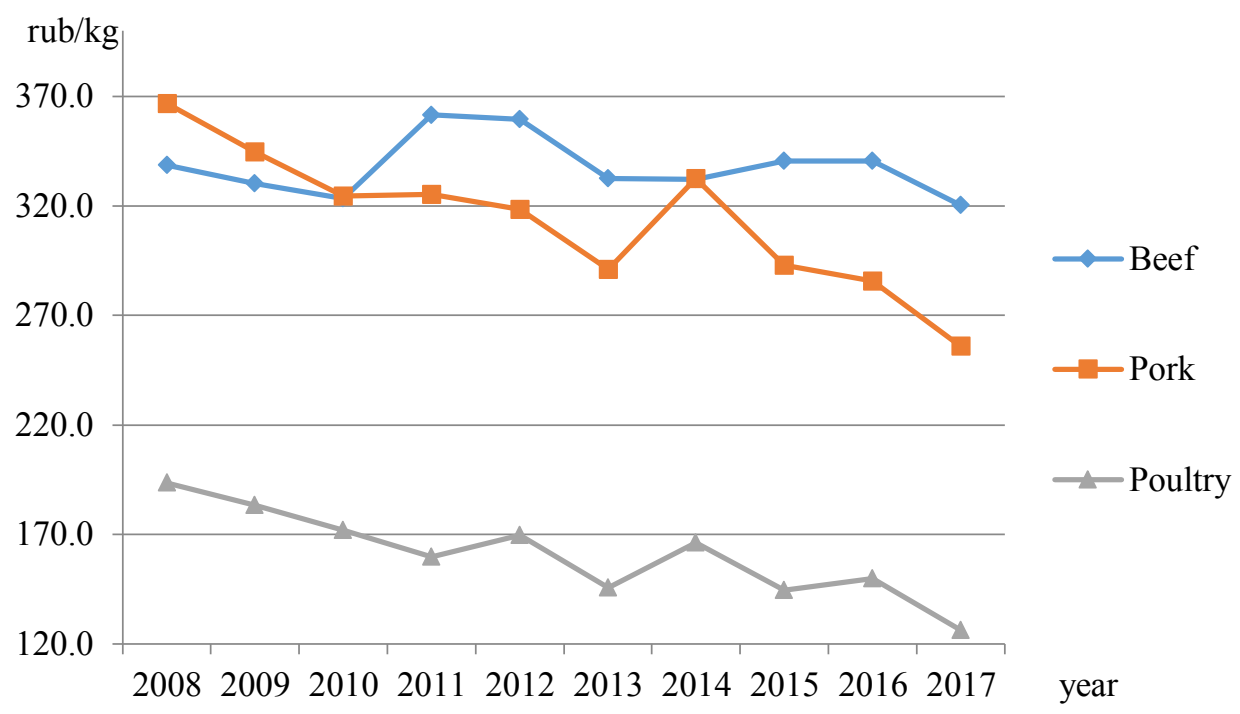

Fig. 4. The level and dynamics of prices for the main types of meat in the Russian Federation in comparable prices by 2017 [8].

The level and dynamics of prices respectively affects the consumption of meat per capita. One of the most important and main target indicators of food security is the level (degree) of achieving optimal food consumption per capita. Over the past decade, there has been an increase in consumption of meat of all types by $7 \%$, amounting to $74.5 \mathrm{~kg}$ per capita at the end of the period, while at the beginning of the period, this indicator was 69.2 $\mathrm{kg}$ per capita. [2] (Figure 5).

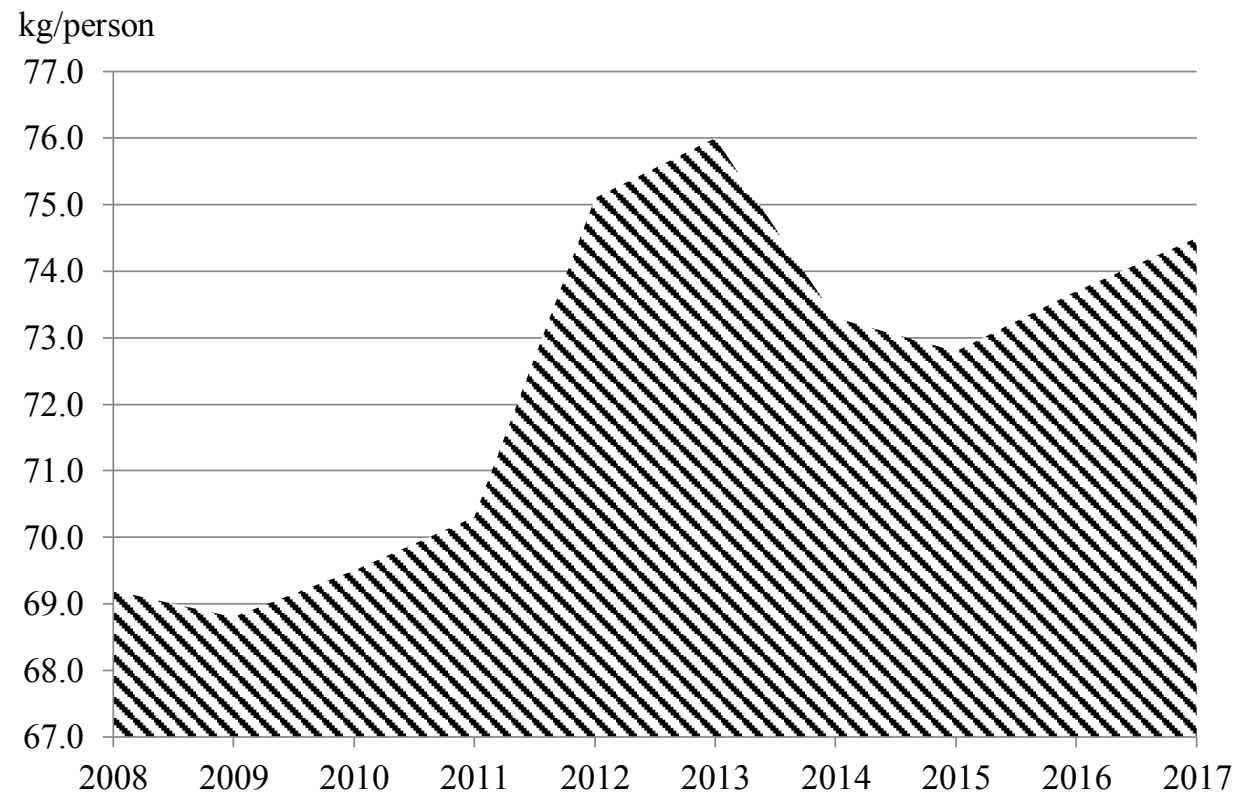

Fig. 5. Assessment of consumption of meat of all kinds in Russia per capita, kg. [9]. 


\section{Russian poultry market}

Analyzing the production of poultry meat in Russia, it can be seen that in 2017 , relative to 2016, the production of poultry meat in the Russian Federation increased by $6.9 \%$ (by 318.7 thousand tons), and in 2018, relative to 2017 , it increased by only $0.8 \%$ (by 39.0 thousand tons). Trends for the first 9 months of 2019 also show a slowdown in growth dynamics (Figure 6).

According to the results of 2019 , production is expected to be 4,983.6 thousand tons, which is approximately at the level of indicators for 2018 .

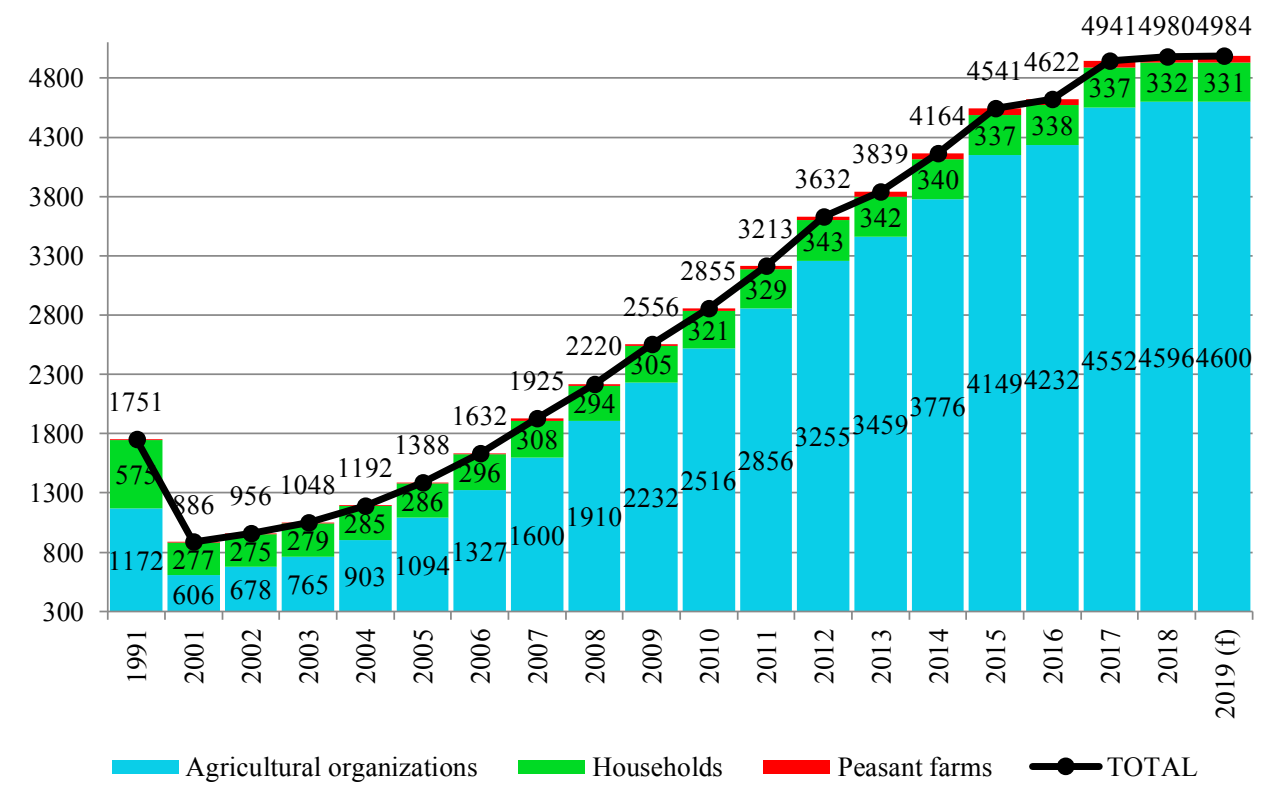

Fig. 6. Production of poultry meat in Russia by categories of farms in carcass weight, in 2001-2018, forecast for 2019, thousand tons Source: Rosstat (Russian Federal State Statistics Service), 2019 forecast by $\mathrm{AB}-$ Centre $[4,5]$.

Between 2001 and 2013, the volume of the market and per capita consumption of pork in Russia constantly had an upward trend. In connection with the imposed sanctions, the market dipped slightly in 2014 (Figure 7). According to forecasts, in 2019, the market volume will be at the level of 3,944.2 thousand tons (pork, offal and salted pork fat). 


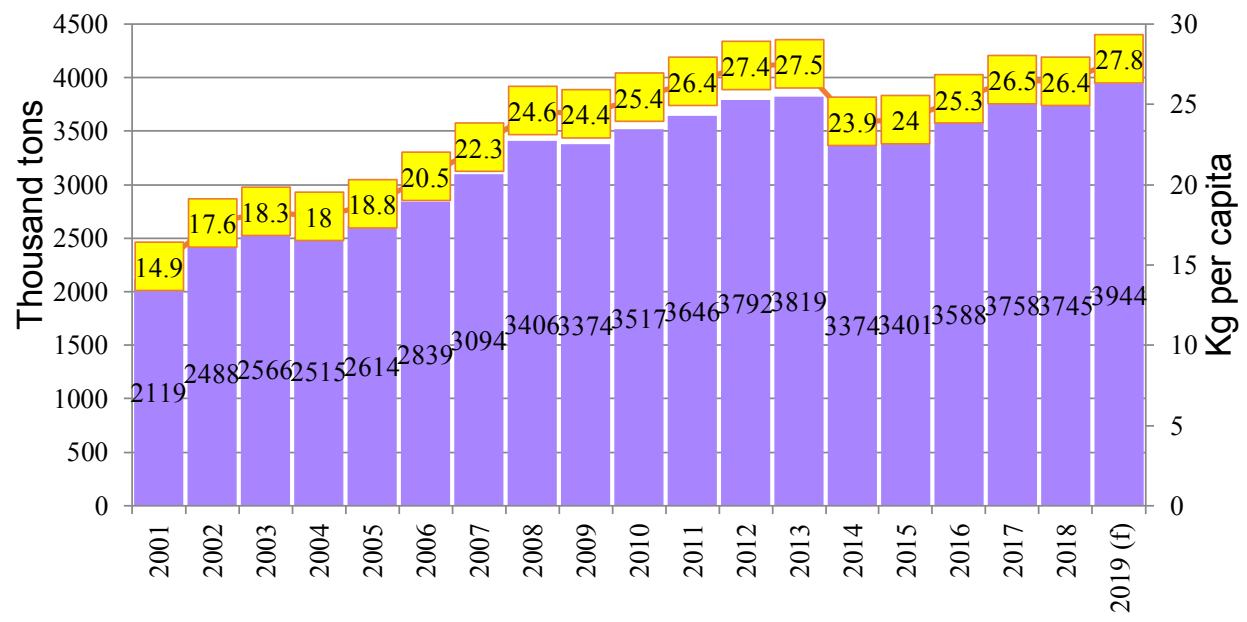

Market volume, thousand tons $\quad \square-$ Per capita consumption, $\mathrm{kg}$

Fig. 7. The volume of the pork market in Russia in 2001-2018, forecast for 2019, thousand tons. Pork consumption per capita, $\mathrm{kg}$ (Source: AB-Centre [5]).

At the same time, per capita consumption of pork will also grow and will reach record levels in $2019(27.8 \mathrm{~kg})$.

In 2018, the self-sufficiency of the Russian Federation with pork reached $100.0 \%$. Volumes of production equaled those of consumption. Import and export were almost at the same levels (if we take into account the total volume of pork, offal and salted pork fat).

\section{Russian lamb market}

The Russian lamb market is characterized by a significant steady increase in the number of sheep in 2001-2016 and a reduction in the number of sheep in 2017-2019 (Figure 8). This is primarily caused by the intensification of slaughter of animals in the context of expanding exports of lamb meet from Russia. In addition, the export of live sheep for their subsequent slaughter abroad has significantly increased. In conditions of high demand, the livestock population has not yet had time to recover. 


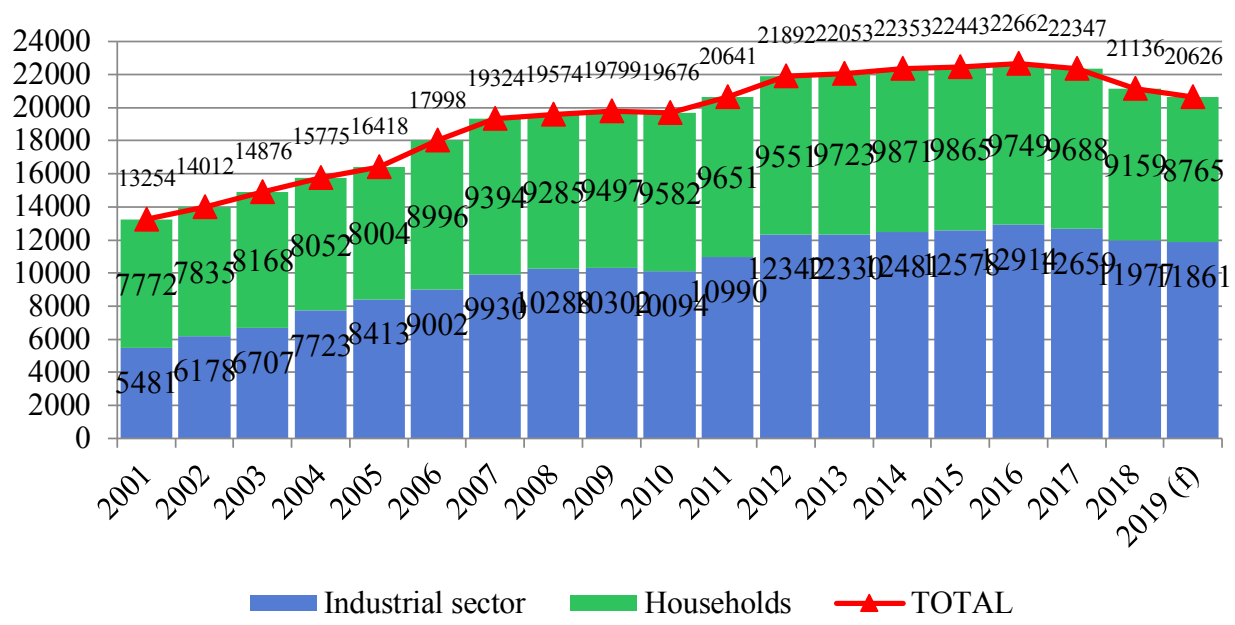

Fig. 8. The number of sheep in Russia by farm category in 2001-2019, data as of the end of the year, thousand heads Source: Rosstat (Russian Federal State Statistics Service), 2019 - forecast by ABCentre $[4,5]$.

Lamb production shows an increase in 2001-2018. However, in 2019, due to a reduction in the number of sheep (which has been observed for more than two consecutive years), a slight decrease in meat production is also expected. In the first three quarters of 2019, it decreased by $3.4 \%$ compared to the same period in 2018 .

\section{Food independence}

Self-sufficiency (food independence) - an indicator characterizing the share of Russian products in the domestic market. It is defined as the ratio of production to consumption. The Food Security Doctrine of the Russian Federation defines a minimum threshold for self-sufficiency in meat. If a country can provide itself with meat by $85 \%$ and above, food independence for meat is considered achieved.

In 2014, the minimum threshold for Russia's food independence in meat was reached for the first time, which, according to the Food Security Doctrine, should be at least $85 \%$. In particular, self-sufficiency of the Russian Federation in pork amounted to $100 \%$ in 2018 (Figure 9).

In 2018, the self-sufficiency of the Russian Federation in meat reached 95.8\%, it is expected to be $96.0 \%$ in 2019 [5]. 


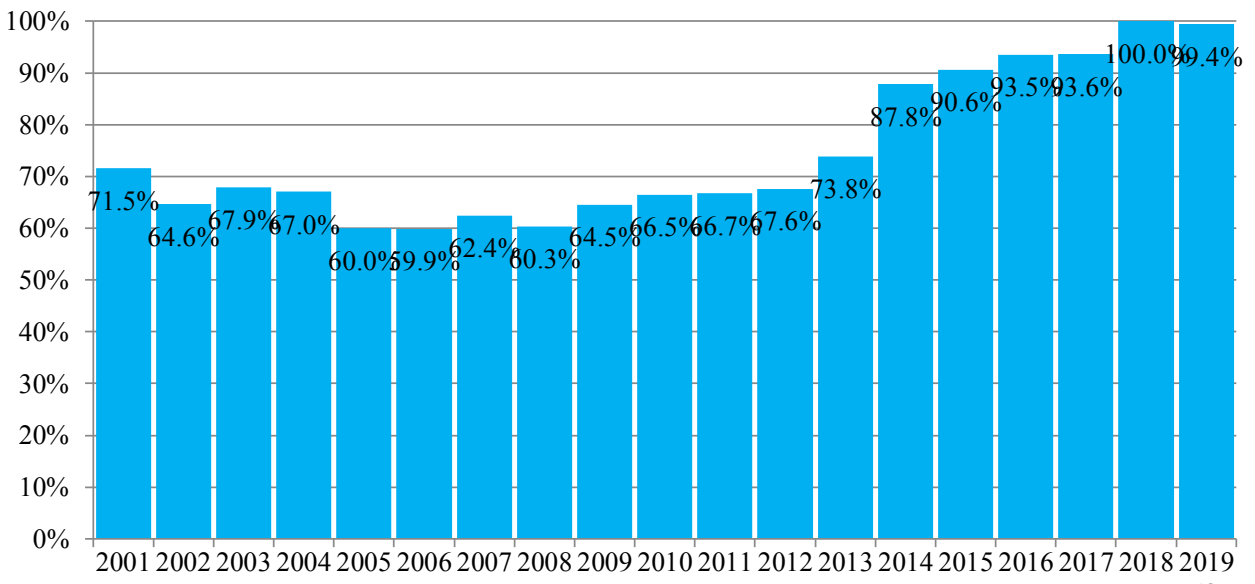

Fig. 9. Russia's self-sufficiency in pork in 2001-2018, forecast for 2019, kg. Source: calculations of AB-Centre [5].

It should also be noted that the Food Security Doctrine of the Ministry of Agriculture set a goal of Russian food market self-sufficiency, in which meat and meat products were given a threshold value of at least $85 \%$. In 2014, the percentage of self-sufficiency of the Russian market for meat products was $84.4 \%$ and almost met the norm, while by the end of 2017, the market was completely self-sufficient.

\section{Import}

Meat import to Russia steadily increased in 2001-2008. Since 2009, supplies have tended to decline. In 2008, the import of meat of all kinds, as well as offal and salted pork fat in the Russian Federation reached 3618.0 thousand tons (Figure 10).

In 2018, meat imports decreased to 756.1 thousand tons. According to the results of 2019 , meat imports are expected to decline to 738.2 thousand tons [5]. 


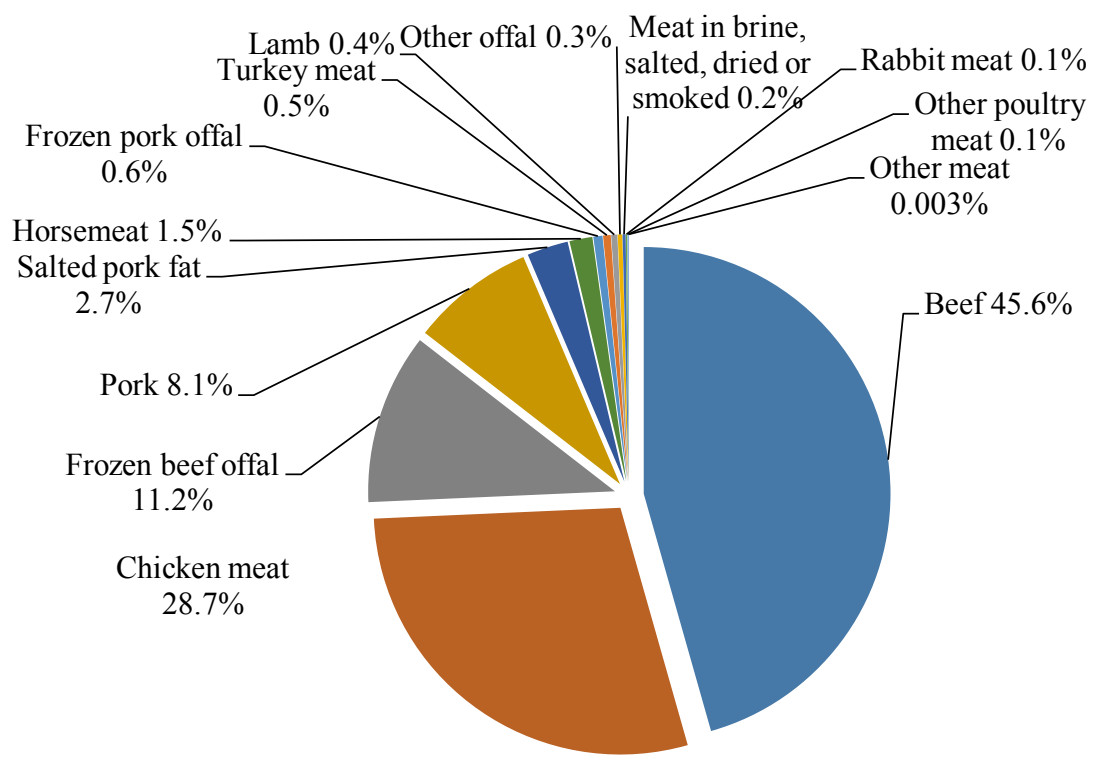

Fig. 10. Structure of meat imports to Russia by type in 2018,\% (Source: calculations of AB-Centre [5]).

The reduction in pork imports to Russia was mainly in 2014. So, if in 2013 the import of pork, offal and salted pork fat in the Russian Federation reached 1011.7 thousand tons, then in 2014, the volumes reduced to 427.7 thousand tons. In 2015-2016, the trend continued (in 2016, imports reduced to 286.4 thousand tons). At the same time, the import of offal and salted pork fat reduced grately (Figure 11).

In 2017, there was a slight increase in imports (up to 314.5 thousand tons). In 2018, under the conditions of a partial ban on imports from Brazil, import volumes fell to 86.0 thousand tons.

In 2019, there has been some recovery in volumes, which will amount to 119.4 thousand tons at the end of the year.

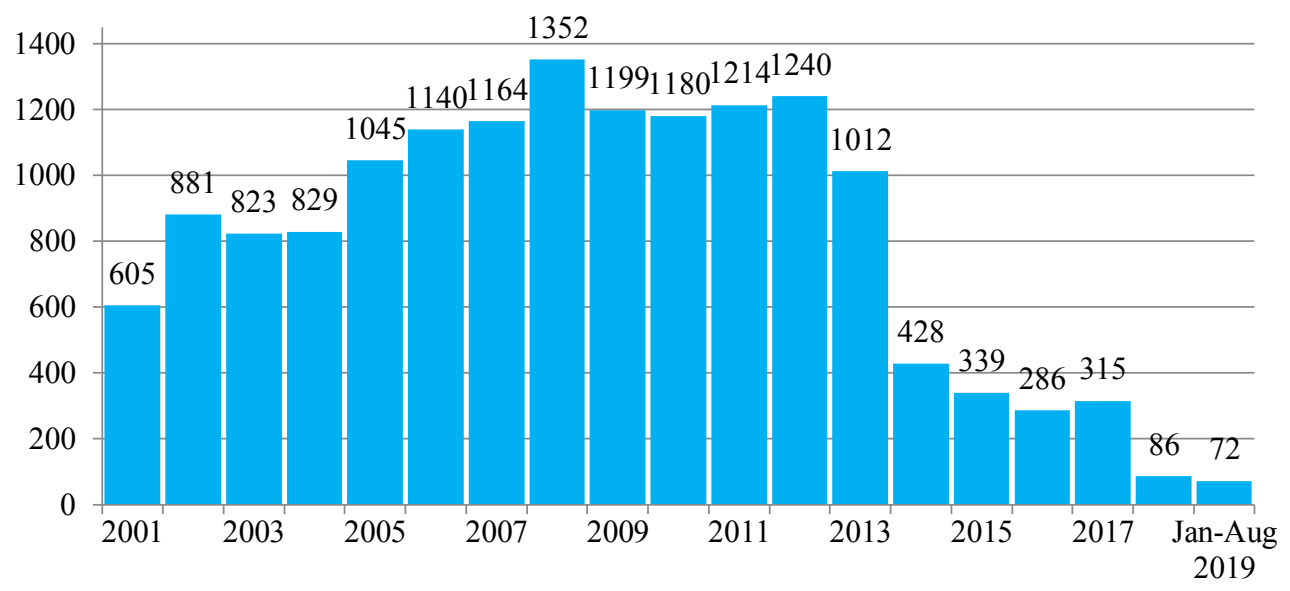

Fig. 11. The volume of pork imports to Russia (including offal and salted pork fat) in 2001-2018, January-August 2019, thousand tons (Source: calculations of AB-Centre [5]). 
The Belgorod region has a pronounced regional concentration of production and is the leading region, where $18.0 \%$ of all pork production in the country is concentrated.

At the same time, imports to other regions of the Russian Federation are carried out in significant volumes (from 100 thousand tons and above) by 5 regions (the main region is the Belgorod region with the possibility of selling 632.7 thousand tons of pork in carcass weight outside their borders), in tangible volumes (from 20 to 100 thousand tons) - 7 regions.

In 54 regions, production volumes were lower than consumption volumes. In 8 regions, requirements for imports are estimated at 50 thousand tons and higher. Among the key recipient regions are Moscow (import requirements - 331.7 thousand tons), Moscow Region (152.0 thousand tons), St. Petersburg (141.8 thousand tons), and Krasnodar Krai (85.5 thousand tons) [6].

\section{Export}

The basis of export deliveries in 2018 was: chicken meat $-62.0 \%$ of all volumes, pork offal - $16.8 \%$, pork $-11.6 \%$, and lamb $-4.3 \%$.

As expected, the growth of exports of pork and other products of the pig industry will continue in the context of expansion of production and steady demand in world markets. At the end of 2019, volumes can increase to 94.3 thousand tons.

Expansion of export volumes is expected to become one of the key drivers of the Russian pork market in the medium and long term. This is due to an increase in global demand for meat. World pork trade is growing annually. Over the past 10 years, global imports of pork grew by $24.2 \%$ (by $2,195.0$ thousand tons).

In 2018, poultry meat exports from Russia amounted to 183.8 thousand tons, which is $12.3 \%$ (20.2 thousand tons) more than a year earlier (Figure 12). 

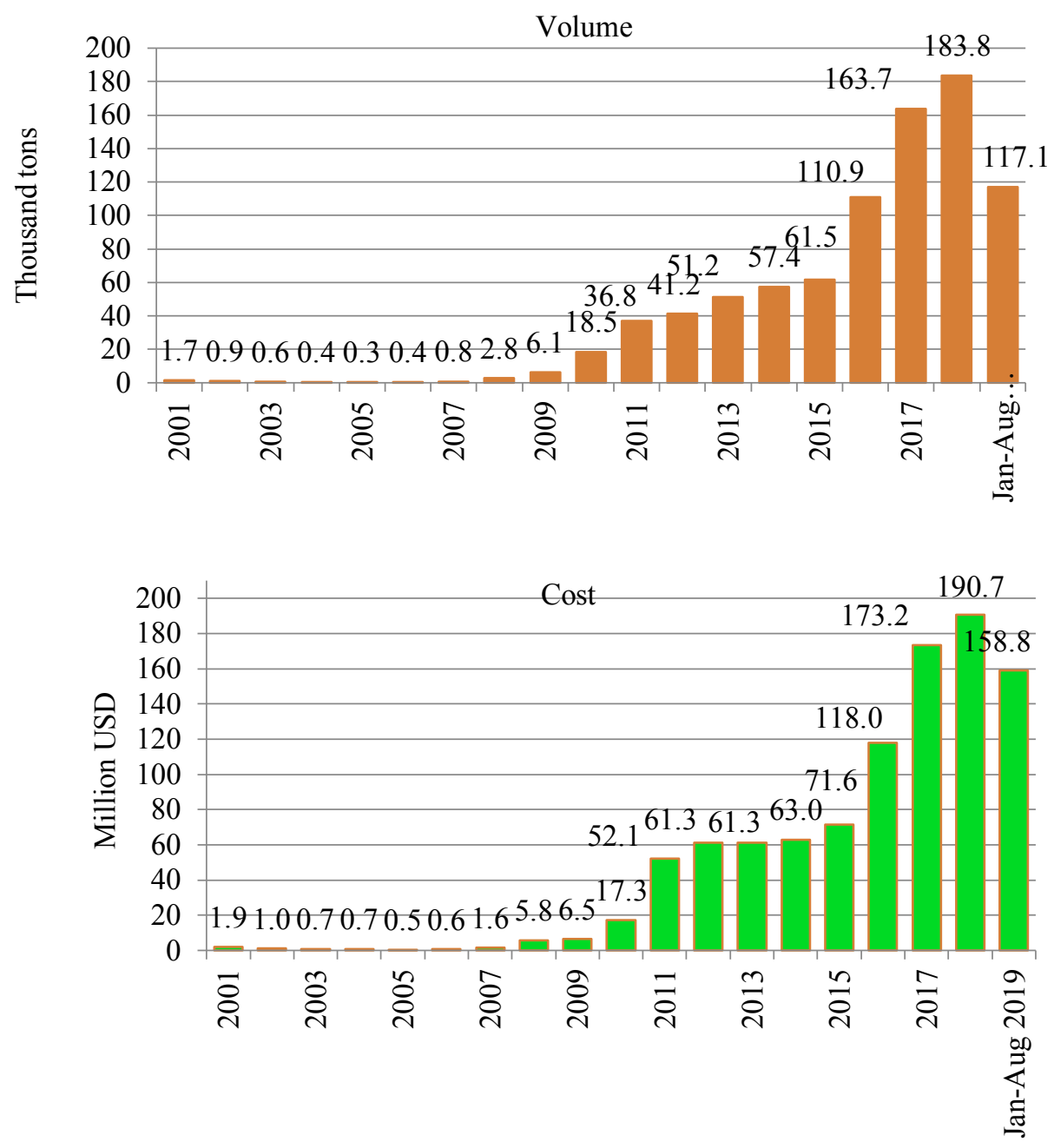

Fig. 12. Export of poultry meat from Russia in 2001-2018, thousand tons Source: calculations of ABCentre [5].

For comparison, 5 years ago (in 2013), export of poultry meat from the Russian Federation was 51.2 thousand tons, 10 years ago (in 2008) - 2.8 thousand tons, in $2001-1.7$ thousand tons.

In 2018 , relative to 2017 , total volumes (pork, offal, salted pork fat) increased by $17.4 \%$ to 85.0 thousand tons.

At the same time, offal prevails in total deliveries - 57.3\%. If we consider pork, then whole meat mainly exported from the Russian Federation. The share of pork sides is $65.0 \%$ of all shipments.

In 2018, lamb exports from Russia were at their highest levels in recent years and amounted to 12,373.3 tons. For comparison, in 2017 - 463.2 tons, in 2013 (5 years ago) 21.0 tons, in 2008 (10 years ago) - 3.0 tons (Figure 13). 

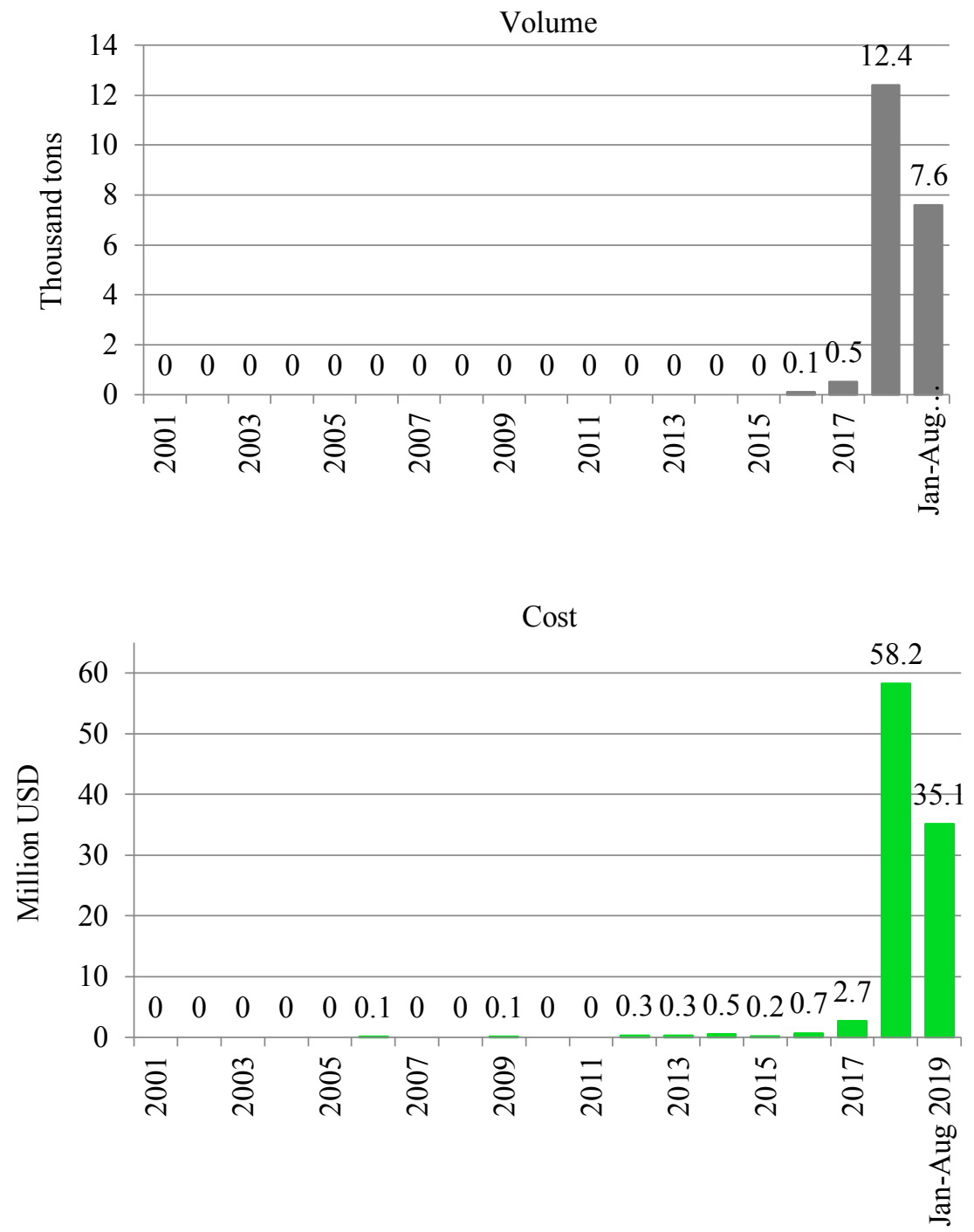

Fig. 13. Export of lamb from Russia in 2001-2018, forecast for 2019 Source: calculations of ABCentre [5].

A significant increase in the export of lamb from Russia was observed in 2017-2019. If in 2016, the export of lamb from Russia was almost at zero, then in 2017, it grew to 0.5 thousand tons. In 2018, it reached 12.4 thousand tons. This is a rather substantial volume for the Russian lamb product market (Figure 14). 


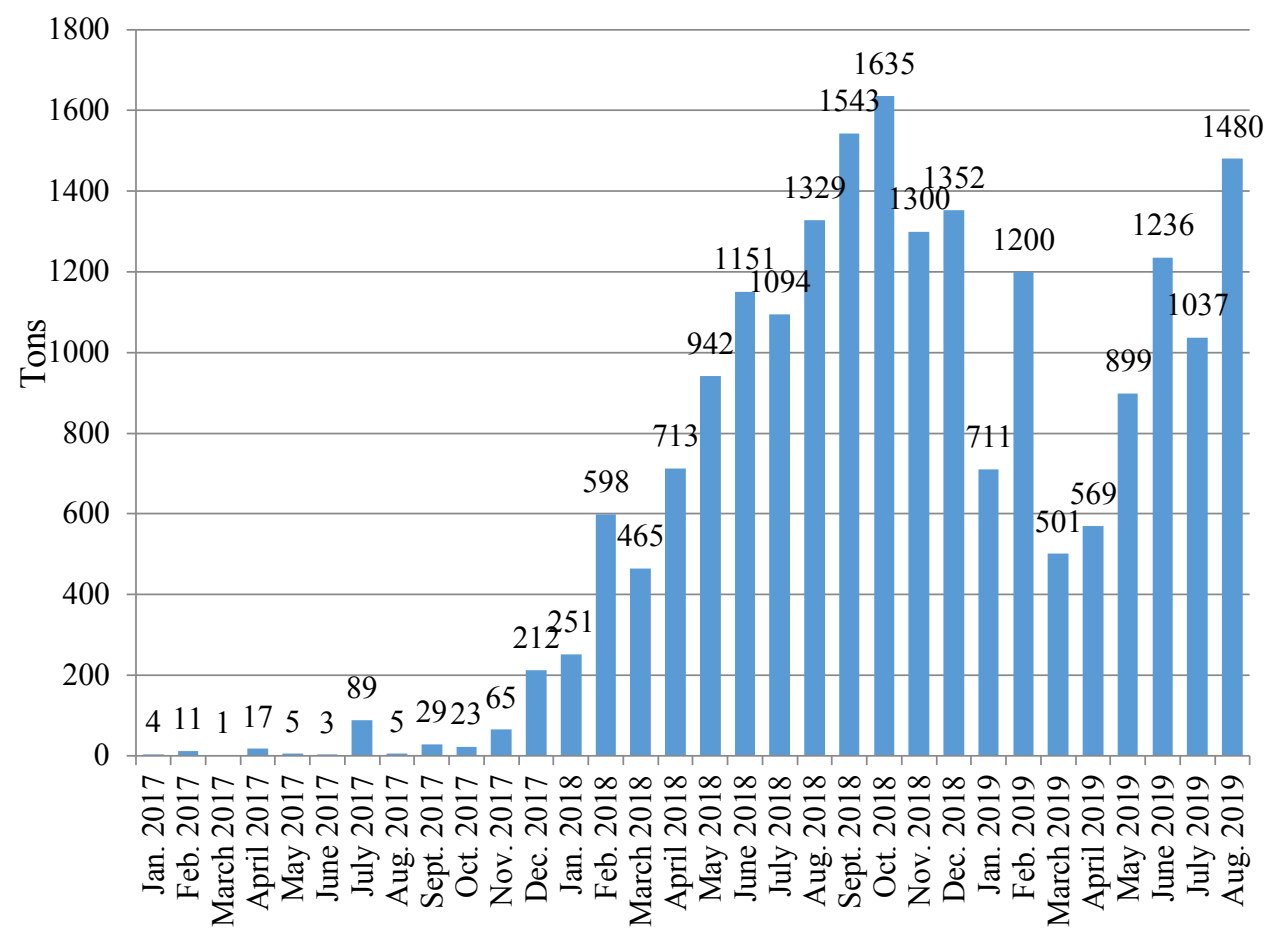

Fig. 14. Dynamics of volumes of lamb exports from Russia in 2017-2019 (Source: according to the Federal Customs Service of the Russian Federation).

As of the end of 2019, a further increase in exports is expected. In January-August 2019 , compared to the same period in 2018 , deliveries grew by $16.7 \%$.

Almost the only export destination is Iran. Deliveries are made from more than 10 meat processing enterprises in Russia. In Iran, more than 20 companies purchase Russian products.

If deliveries continue to be carried out in significant volumes, the export sector will become one of the key drivers for the development of the sheep industry and the lamb processing industry in Russia.

In 2018, exports of live sheep from Russia for their subsequent slaughter reached 7.8 thousand tons against 4.5 thousand tons in 2017 and 0.6 thousand tons in 2016, which was a significant increase.

Exports of live sheep from Russia in 2018 amounted to 7762.1 tons. For comparison, in 2017 - 4,468.3 tons, in 2016 - 564.1 tons, in 2015 - 1,529.4 tons (Figure 15). 

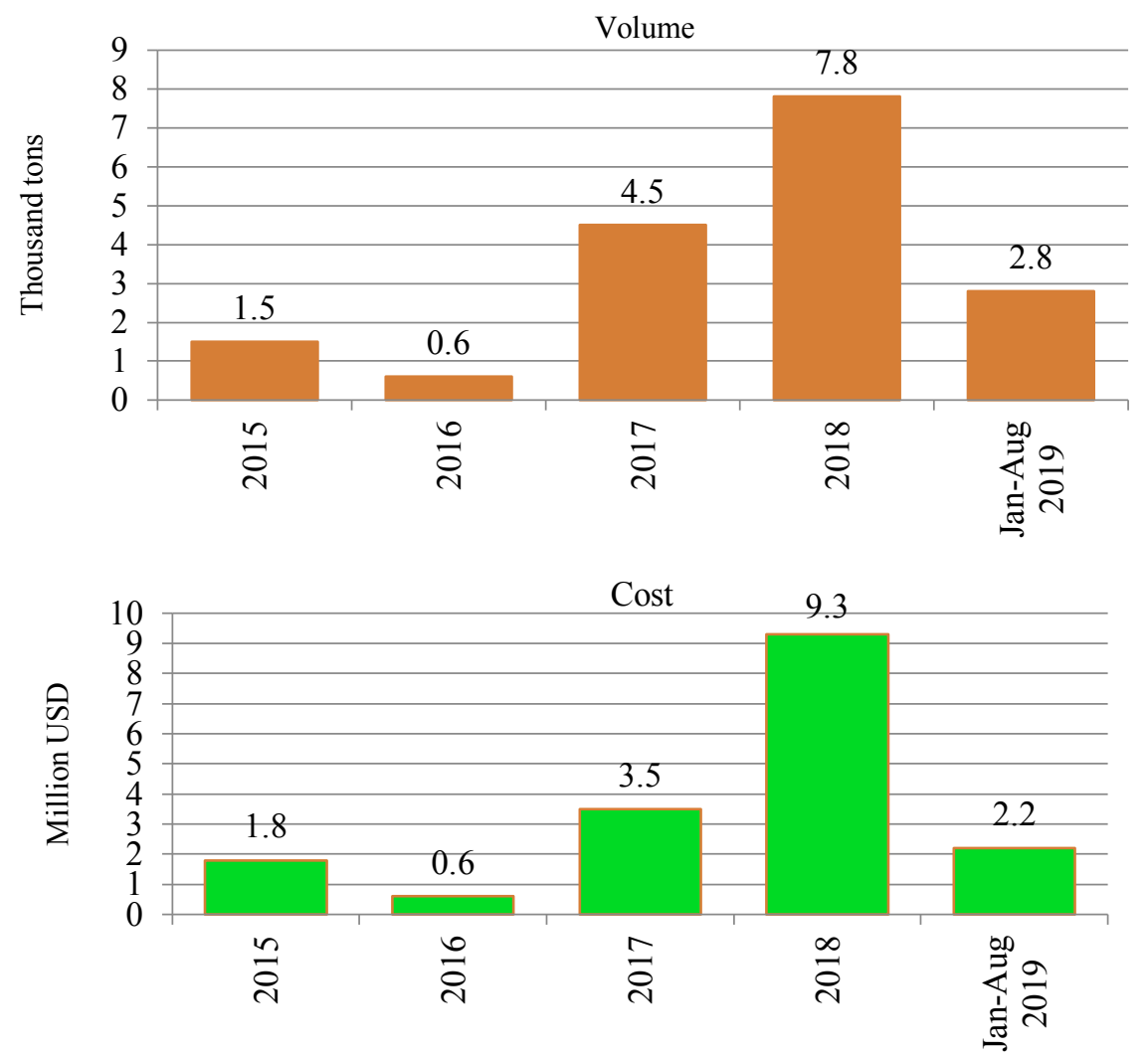

Fig. 15. Export of live sheep from Russia 2015-2018, forecast for 2019 (Source: calculations of ABCentre [5].

In January-August 2019 , deliveries were at $2,814.8$ tons, which is $8.7 \%$ (268.3 tons) less than in the same period in 2018.

\section{Discussion}

How badly uncontrolled imports affect the state of domestic production is evidenced by the sad experience of the 90s. At that time, the agricultural sector of the Russian economy was almost completely destroyed as a result of reforms and the "redistribution of property". And the surviving remnants of the agricultural business were literally swept away by a wave of cheap imported food.

At the same time, foreign suppliers benefited twice. On the one hand, they got the opportunity to realize surplus or waste from their production. It's known, for example, that the Americans didn't buy "Bush legs", preferring more dietary breasts and wings. On the other hand, deliveries of food at dumping prices "smashed" Russian producers, thus ensuring future demand for imported products.

Reducing imports is a necessary measure for the development of domestic livestock breeding.

The first attempts to protect the Russian market from imports were made in the early 2000s. The default of 1998 made imports unprofitable and helped the revival of the domestic agricultural industry. 
There is a continuous fight about the rules of import. It is clear that the interests of domestic producers are directly opposite to the interests of foreign exporters. At the same time, the latter often resort to all kinds of frauds in the pursuit of profit. For example, Polish producers collect pork from wherever possible, but not from the safest places, and give their certificate to these products. Then this pork goes to Russia. Victory in this confrontation is largely determined by the strength of the farm lobby of the respective countries.

Although, the restriction of imports may lead to higher prices for meat in the short term, but it will help increase its production in the future due to a reduction in the payback period.

According to the authors, “... there is a need to adjust customs and tariff regulation by carefully analyzing trends in food markets. When quoting, it is necessary to take into account not only all types of meat and meat products, but also the import of live poultry, pigs and cows" [10-15].

The effectiveness of state support in the form of subsidies and grants is evidenced by the fact that thanks to the government subsidizing domestic production of pork, imports of these products fell by $15 \%$.

Russia abolishes quotas for pork imports in 2020 as part of tariff obligations to the WTO. There will be a flat tariff with a custom duty at the level of $25 \%$. Nowadays, there is a zero quota rate and a rate of $65 \%$ out of quotas. The size of the quota in recent years has been 400 thousand tons. As can be seen from the analysis of pork imports in the relevant section of this study, the quota for pork in 2015-2019 was not selected even in the conditions of zero custom duty. In this regard, one should not expect a tangible expansion of imports. In addition, in recent years, Russian products have become competitive in price both in the domestic and global markets.

In November 2019, a workshop on the issue of canceling tariff quotas for beef imports and switching to a flat import duty was held at the Ministry of Agriculture of the Russian Federation.

The National Union of Beef Producers, the National Association of Cattle Producers, the National Meat Association, and the National Union of Milk Producers approached the Government of the Russian Federation with an initiative to review the current mechanism of tariff quotas.

The mechanism of tariff quotas for beef imports contributed to the creation of conditions for the start of projects in beef cattle breeding, and more rational use of the dairy herd that is outside the lactation. The rate of decline in cattle stock decreased. Important changes are observed in the structure of the cattle stock - an increase in cattle production in agricultural organizations and peasant farms, an increase in the share of specialized cattle of beef and cross breeds. All this allows increasing the efficiency of the industry.

However, an analysis of the supply of beef from non-CIS countries shows that in recent years, tariff quotas have ceased to fulfill their regulatory role. Even taking into account the fact that part of the quotas is not allocated taking into account special economic measures and, in fact, only the "Other countries" quota operates, more than half of the quota provided for frozen beef and almost $90 \%$ of the quota provided for fresh and chilled beef is not taken up.

Domestic beef prices have been stable in recent years. The abolition of tariff quotas and the historical principle of quota allocation will also help expand the potential circle of beef importers, including meat processing plants, which will increase market competition and provide, if necessary, a more flexible response to changes in the external and internal market conditions. 


\section{Conclusions}

International demand for beef is ahead of global supply, so high demand from Asia is expected, which will stimulate higher prices for imported beef. Next year, global beef production is expected to grow by $1 \%$. The main growth will take place in South America and the USA. The US cattle stock is entering a reduction phase, which will provide export support in the short term.

Last year, global meat production increased by a total of $1.25 \%$ to 323 million tons, according to the latest global market report published by the Organization for Economic Co-operation and Development (OECD) and the Food and Agriculture Organization of the United Nations (FAO).

FAO predicts that over the next 10 years, beef and lamb will gain popularity in the global market. The USA, along with China, Argentina, India, Mexico, Russia and Turkey, made the main contribution to this development. In the near future, analysts expect a slight decrease in meat prices due to an increase in meat supplies, which is associated with an increase in livestock, which is observed in some countries. According to forecasts, world meat production will be $15 \%$ higher in 2027 relative to the base period. Poultry meat remains the main growth factor in total meat production, but in the next decade, growth in poultry meat production will slow significantly compared to the previous one. Analysts estimate that growth in global demand for animal proteins over the next decade will slow down for poultry and pork, but increase for beef and sheep meat. Brazil and the United States will cover $47 \%$ of the global market share, contributing to nearly two-thirds of expected growth in global meat exports during the forecast period. World trade will continue to depend on factors such as outbreaks of animal diseases, sanitary restrictions and trade policies, as well as consumer preferences and attitudes towards meat consumption in general.

It should be noted that the main role of the quality of meat products depends, first of all, on effective measures of state support to the industry, which contribute to stimulating the intensification of production of meat and meat products, developing regions, and increasing consumption of these products.

Based on the results of the analysis, it can be concluded that providing the population with meat products is an important task that can be solved through the development of pedigree livestock breeding, beef cattle breeding and complexes for processing meat into finished products.

\section{References}

1. L.V. Shabalina, N.V. Alekseev, Economic Bulletin of Donbass 55(1), 79-86 (2019)

2. L.A. Kopteva, D.A. Smolnitskaya, Materials of the XVIII International scientific and practical conference "YOUTH AND SCIENCE", 302-306 (AESA, Almaty, 2019)

3. K.G. Borodin, Issues of Economics 4, 124-143 (2016)

4. A. Plugov, Russian meat market 2019. Trends and forecasts. The expert analytical center of agrobusiness "AB-Centre", https: // www.ab-centre.ru

5. Russian statistical yearbook. The official portal of Rosstat (Russian Federal State Statistics Service), https://www.gks.ru

6. Market of meat and meat products 4, 33-35 (2018)

7. A.I. Altukhov, APK: Economics, Management 2, 19 - 29 (2014)

8. Unified interdepartmental information and statistical system (EMISS), https://www.fedstat.ru 
9. M.V. Klinova, E.A. Sidorova, Voprosy Ekonomiki (Issues of Economics) 12, 67 - 79 (2014)

10. L. Kopteva, L. Shabalina, A. Prorokov, MATEC Web Conf. International Science Conference SPbWOSCE - 2017 «Business Technologies for Sustainable Urban Development» 170 (2018) https://doi.org/10.1051/matecconf/201817001054

11. L. Kopteva, L. Shabalina, E. Kashirina, E3S Web of Conferences 91, 06011 (2019) https://doi.org/10.1051/e3sconf/20199106011

12. L.A. Kopteva, L.V. Shabalina, On issues of world food security. Financial economics 4(1), 59 - 61 (2018)

13. E. Ganebnykh, T. Burtseva, A. Petuhova, A.Mottaeva, , E3S Web of Conferences, 91,08035, (2019) doi.org/10.1051/e3sconf /20199108035

14. K.G. Borodin, Voprosy Ekonomiki (Issues of Economics) 4, 124-143 (2016)

15. E.T. Gurvich, I.V. Prilepsky, Voprosy Ekonomiki (Issues of Economics) 1, 5-35 (2016) 